\title{
Vitis vinifera L.: Wild or cultivated? Study of the grape pips found at Petra, Jordan; 150 B.C. - A.D. 40
}

\section{Journal Article}

\section{Author(s):}

Jacquat, Christiane; Martinoli, Danièle

Publication date:

1999

\section{Permanent link:}

https://doi.org/10.3929/ethz-b-000423125

\section{Rights / license:}

In Copyright - Non-Commercial Use Permitted

\section{Originally published in:}

Vegetation History and Archaeobotany 8(1-2), https://doi.org/10.1007/BF02042839 


\title{
Vitis vinifera L.: wild or cultivated? Study of the grape pips found at Petra, Jordan; 150 B.C. - A.D. 40
}

\author{
Christiane Jacquat and Danièle Martinoli ${ }^{1}$ \\ Geobotanical Institute, Swiss Federal Institute of Technology, Zollikerstrasse 107, CH-8008 Zurich, Switzerland
}

Received June 15, 1998 / Accepted August 25, 1998

\begin{abstract}
The identification of carbonised grape pips (Vitis vinifera ssp.) is problematic, and the morphological features generally used to distinguish the wild subspecies $V$. vinifera ssp. sylvestris from the cultivated subspecies $V$. vinifera ssp. vinifera are not satisfactory. Different biometric studies were carried out on Nabataean and Roman seeds found at Petra, Jordan, dated to 150 B.C. - A.D. 400 , and the results were compared to known phytogeographical and climatic data. Depending on the identification method selected, the seeds were attributed either to wild grapevines (based on the ratio of breadth over length, and on discriminant analyses of size variables such as pip length, stalk length, and chalaza position), or to an archaic variety of vine with seeds morphologically close to those of wild grapevines (ratio of stalk length over total pip length). The methods used here were applied to European grape pips; they should be tested on Near Eastern material. Archaeological data did not clarify the situation, and the importance of viticulture, which was prohibited during the Nabataean period, remains difficult to evaluate at Petra.
\end{abstract}

Key words: Identification - Grapevine - Archaeobotany - Nabataean period - Jordan-Petra

\section{Introduction}

Grapevines were among the first fruit to be cultivated in the Middle East and the Mediterranean periphery. This practice seems to have originated in the Levant as early as the second half of the 4th millennium B.C. The numerous fruits, pips, and wood remains found at sites located outside the distribution area of wild grapevines, for instance at Tell Shuna (Jordan; Chal colithic), Jericho (Cisjordan; early Bronze Age) and Arad (Israel; early Bronze Age), seem to indicate that viticulture had been practised at that time (Zohary and Spiegel-Roy 1975; Hopf 1978, 1983; Zohary and Hopf 1993).

Correspondence to: Chr. Jacquat
Thus, the grape pips recovered at Petra, Jordan (archaeological campaigns 1991-1994, University of Basel, Switzerland), dated between 150 B.C. and A.D. 400, appear a priori to have come from cultivated vines. This is in contradiction to the Nabataean laws reported in the $4^{\text {th }}$ century B.C. by Diodorus (Diod. 19, 94, 2), which prohibited cereal and fruit tree cultivation, as well as wine consumption: these activities could be punished with the death penalty. But how can one differentiate wild from cultivated grapevines?

\section{Wild and cultivated grapevines}

Wild grapevines, Vitis vinifera L. ssp. sylvestris (C.C. Gmel.) Hegi, are dioecious and display morphological characteristics which are similar to those of cultivated grapevines ( $V$. vinifera L. ssp. vinifera). The pips of sub-

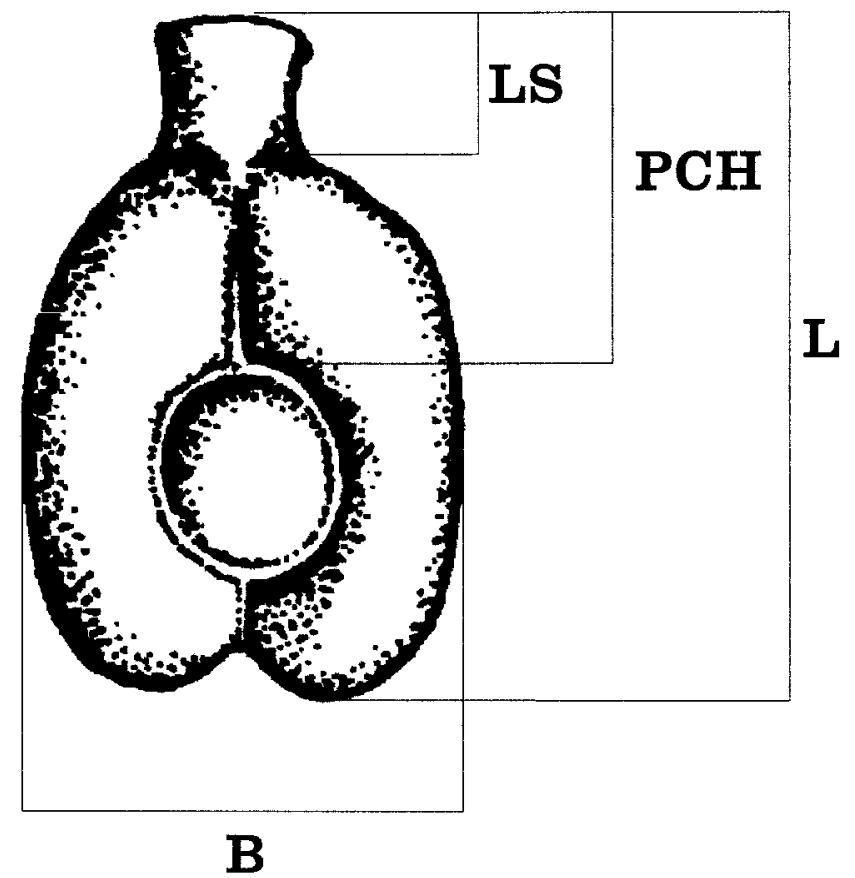

Fig. 1. Sketch of a grape pip showing position of measurements (after Kislev 1988, Mangafa and Kotsakis 1996). L: length, LS: stalk length; PCH: chalaza position, B: breadth 
species sylvestris are smaller than those of subspecies vinifera and more globular, with a massive, short and truncated stalk, which tapers slightly towards the base. Their shape also depends on the number of seeds in the berry (in general three). The subspecies vinifera pips are larger, pyriform, with an elongated stalk. These criteria are not sufficient to differentiate the two subspecies.

The calculation of Stummer's index, based on the ratio of the pips' breadth over their length $(B / L \times 100$; Fig. 1 ), enables one to distinguish wild grapes, with indices of 76-83, from cultivated ones, with indices of 44-53. Pips with an intermediate index, however, cannot be attributed to a subspecies (indices of 54-75; Stummer 1911). This index is based on the study of Austrian wild and cultivated grapevines and has often been used to differentiate charred pips from archaeological sites.

However, studies of the effects of carbonisation have shown that the ratio of $\mathrm{B}$ over $\mathrm{L}$ increases when charring takes place, so that this formula cannot be applied to charred seeds. Pips from cultivated grapes become smaller and rounder when charred; their length tends to decrease (Logothetis 1970, 1974; Smith and Jones 1990).

Recently, discriminant analyses including up to five pip characters have made the distinction between carbonised modern wild and cultivated grapes from Greek populations possible. The formulae proposed by Mangafa and Kotsakis (1996) were successfully applied to local Greek archaeological remains. The four formulae (given below) are based on the statistical treatment of variables such as pip length (L), stalk length (LS), and chalaza position (PCH; Fig. 1). The measurement of stalk length is often imprecise, as the stalk base is difficult to recognise and its tip is often truncated. However, an error probability of $0.2 \mathrm{~mm}$ is included in Mangafa and Kotsakis' formulae, as well as eventual deformations due to temperatures which may reach up to $450^{\circ} \mathrm{C}$.

Formula 1:

$-0.3801+(-30.2 \mathrm{LSL}+0.4564 \mathrm{PCH}-1.386 \mathrm{~L}+2.88 \mathrm{PCH} / \mathrm{L}+9.4239 \mathrm{LS})$

Formula 2:

$0.2951+(-12.64 \mathrm{PCH} / \mathrm{L}-1.6416 \mathrm{~L}+4.5131 \mathrm{PCH}+9.63 \mathrm{LS} / \mathrm{L})$

Formula 3:

$-7.491+(1.7715 \mathrm{PCH}+0.49 \mathrm{PCH} / \mathrm{L}+9.56 \mathrm{~L} / \mathrm{S} / \mathrm{L})$

Formula 4:

$0.7509+(-1.5748 \mathrm{~L}+5.297 \mathrm{PCH}-14.47 \mathrm{PCH} / \mathrm{L})$

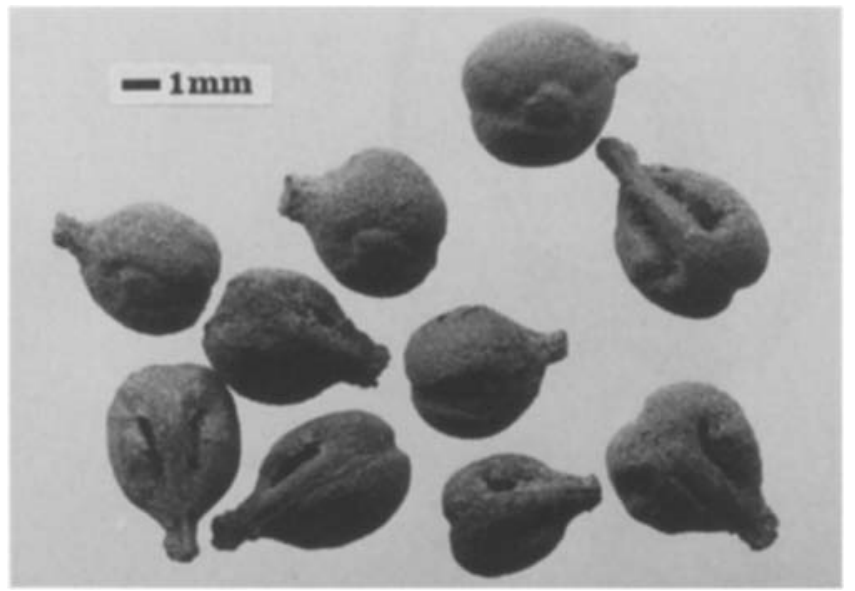

Fig. 2. Charred grape pips from the Nabataean period, Petra, Jordan, 50 B.C - A.D. 100

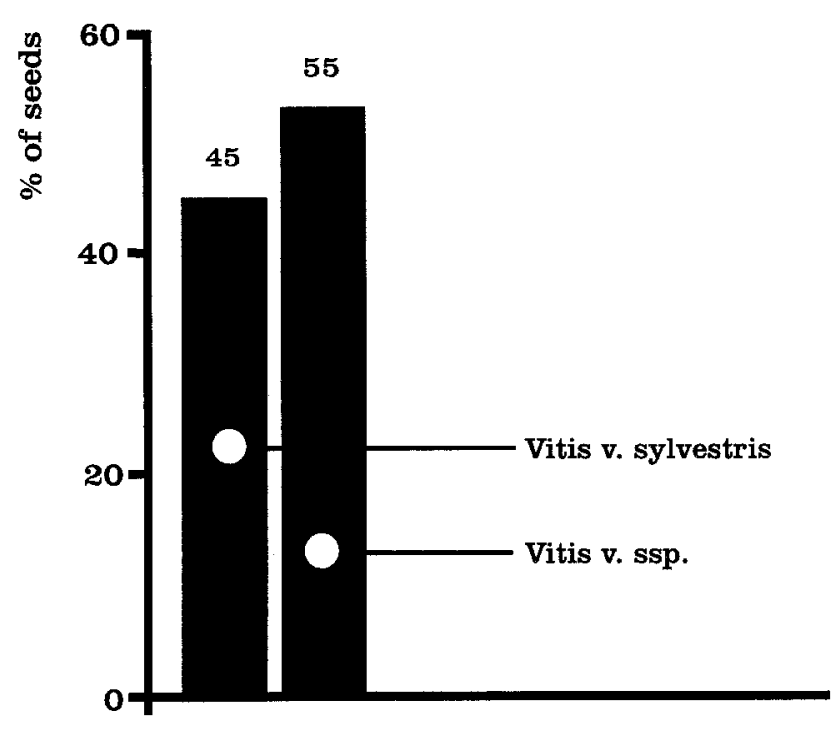

Fig. 3a. Attribution of charred grape pips from Petra, Jordan, according to Stummer (1911)

Values smaller than -0.2 for Formulae 1 and 2, of 0 for Formula 3, and $-\mathbf{0 . 9}$ for Formula 4, indicate wild grape seeds. Values comprised between -0.2 and 0 for Formula 1, between -0.2 and 0.4 for Formula 2, between 0 and 0.5 for Formula 3 , and between -0.9 and 0.2 for Formula 4 , indicate wild grape pips with great probability. Values greater than 0.8 for Formula 1, 0.9 for Formulae 2 and 3 , and 1.4 for Formula 4, indicate cultivated grape seeds. Values between 0.2 and 0.8 for Formula 1, between 0.4 and 0.9 for Formula 2, between 0.5 and 0.9 for Formula 3, and between 0.2 and 1.4 for Formula 4, indicate cultivated grape pips with great probability.

\section{Measurements of the pips found at Petra}

During the excavations of the dwellings in the ez Zantur area at Petra, several hundred whole or fragmented carbonised grape pips were found (Stucky et al. 1995; Karg 1996; Martinoli 1997).

The best-preserved seeds were selected for this study, comprising three pips dating from the early Nabataean period (150-50 B.C.) and 335 pips from the Nabataean period (50 B.C. - A.D. 100); the grape remains from the latter period were the most abundant in our samples. The pips from the late Roman period (4th C. A.D.) were unfortunately too severely damaged to be measured. The measurements were made with a graduated eyepiece in a Leica MZ8 stereoscopic microscope, calibrated with a Wild micrometric slide holder $(100 \times 0.1 \mu=1 \mathrm{~mm})$.

In order to apply the formulae proposed by Mangafa and Kotsakis to our material, as well as Stummer's index for comparison, the following measurements were made on the dorsal side of the archaeological grape pips: pip length (L), stalk length (LS) and chalaza position (the distance from the chalaza base to the stalk tip) $(\mathrm{PCH})$. Stalk length was measured from the base, marked by a swelling of the body, to the tip of the stalk (Fig. 1).

To test Stummer's index, the breadth (B) of 20 Nabataean seeds was measured. 


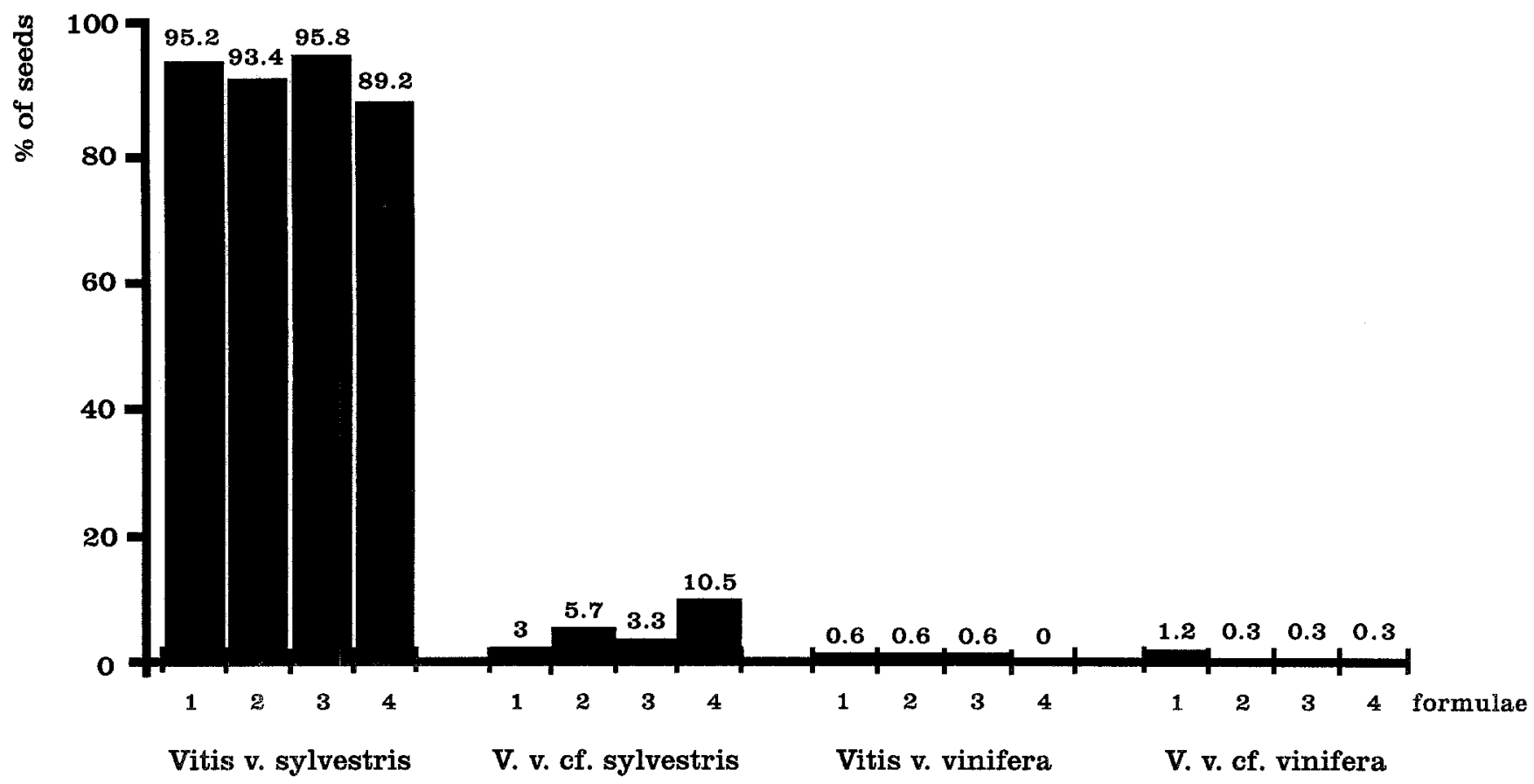

Fig. 3b. Attribution of charred grape pips from Petra, Jordan, according to Mangafa and Kotsakis (1996)

\section{Results}

Morphologically, the grape pips from the three periods under study were very similar, even though the seeds from the late Roman period were badly preserved: they were broadly oval-pyriform in shape, with a short stalk and a wide base (Fig. 2). However, a small number of seeds was atypical, with very variable dimensions.

The mean of the measurements of the three grape pips from the Early Nabataean period were $\mathrm{L}=4.99 \mathrm{~mm}$ (4.5-5.2), LS $=1.14 \mathrm{~mm}(1.0-1.1)$, and $\mathrm{PCH}=2.52 \mathrm{~mm}$ (2.5-2.8). The mean of the measurements of the 335 Nabataean grape pips were $\mathrm{L}=4.0 \mathrm{~mm}(2.5-5.5), \mathrm{LS}=$ $0.83 \mathrm{~mm}(0.5-1.5)$ and $\mathrm{PCH}=2.26 \mathrm{~mm}(1.3-2.9)$. The mean of the breadth measurements of 20 Nabataean pips were $\mathrm{B}=3.38 \mathrm{~mm}(2.8-3.9)$. The complete set of measurements can be obtained from the authors.

\section{Stummer's index}

According to Stummer's index, $45 \%$ of the Nabataean pips belonged to wild grapevines (indices $=75.4-84.7$ ), while the remaining $55 \%$ could be attributed to neither subspecies (indices $=62.9-74.5$; Fig. $3 a$ ).

\section{Formulae of Mangafa and Kotsakis}

On the basis of these formulae the early Nabataean pips and most of the Nabataean pips were classified as being from wild grapevines (89.2-95.8\%). Additionally, $3-10.5 \%$ of the pips could also have belonged to the wild subspecies (probabilities $=64.7-93.3 \%$ according to the formula used). According to Formulae 1, 2 and 3, 0.6\% of the seeds belonged to cultivated grapevines, that is two seeds; according to Formula 4, none; additionally,
$0.3-1.2 \%$ could also have belonged to this subspecies (probabilities $=63.3-76.5 \%$ according to the formula used; Fig. 3b).

\section{Discussion}

According to the formulae of Mangafa and Kotsakis (1996), the pips found at Petra appear to have belonged to wild grapevines (Vitis vinifera ssp. sylvestris); these results were partially confirmed by the calculation of Stummer's index. Only a very small percentage could be attributed to cultivated grapevines. From a phytogeographical viewpoint, wild grapevines are widely distributed from the Spanish and French Atlantic coasts to Tajikistan, but they are absent in Jordan today (Levadoux 1956; Terpò 1976; Rivera Nuñez and Walker 1989; Zohary and Hopf 1993), Fig. 4. They grow along river banks, climbing in the trees of the gallery forest, a habitat which is rare in the region of Petra. The wild vine is abundant in the mesic maquis of the Mediterranean basin, and is also present south of the Black Sea and the Caspian Sea, where the climate is mild and humid. In more southern areas of the Levant, its closest location to Jordan is still unclear: it occurred in south-western Syria and perhaps in northern Israel (Mouterde 1970; Kislev 1988; Kislev et al. 1992).

Today, the vegetation around Petra is composed of Mediterranean, Irano-Turanian and Saharo-Arabian floristic elements. During Nabataean and Roman times, the vegetation was similar and already affected by human activities (Fall 1990; Martinoli 1997). Various taxa such as Quercus calliprinos (kermes oak), Juniperus phoenicea (phoenician juniper) and Ceratonia siliqua (carob tree) reach their most southern geographic limit here. Although the climate was relatively dry in Jordan 


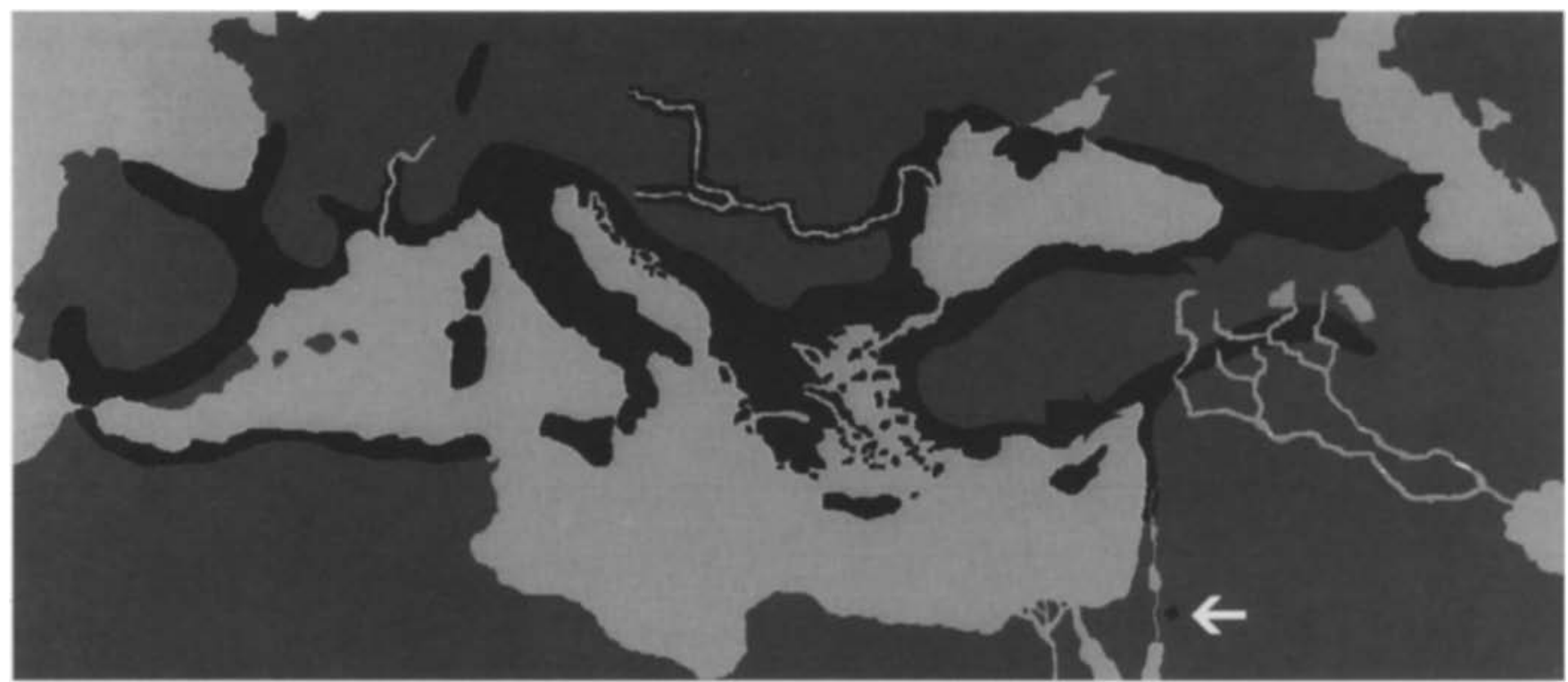

Fig. 4. Distribution map of Vitis vinifera ssp. sylvestris (after Zohary and Hopf 1993). Dark shading represents the recent areas with wild Vitis. The location of Petra is shown by an arrow

from 500 to 200 B.C., rainfall seems to have risen at the beginning of the 1 st century B.C., and a more humid climate was prevalent until the beginning of the $3 \mathrm{rd}$ century A.D. (Shehadeh 1982). This climate may have encouraged the presence of wild grapevines in certain areas of Jordan.

In a recent study comparing the pips of wild grapevines and different varieties cultivated in Europe, Perret (1997) showed that the ratio of stalk length over total seed length remains stable for Vitis vinifera ssp. sylvestris but is very variable for $V$. vinifera $\mathrm{ssp}$. vinifera. These observations are also valid for carbonised pips (Smith and Jones 1990; Mangafa and Kotsakis 1996).

Five varieties of vines were studied: Chasselas, Pinot Noir, Rèze, Amigne and White Humagne. The mean LS/ L X 100 (stalk length/pip length x 100) values of their seeds varied between $21-29(100$ seeds per variety were

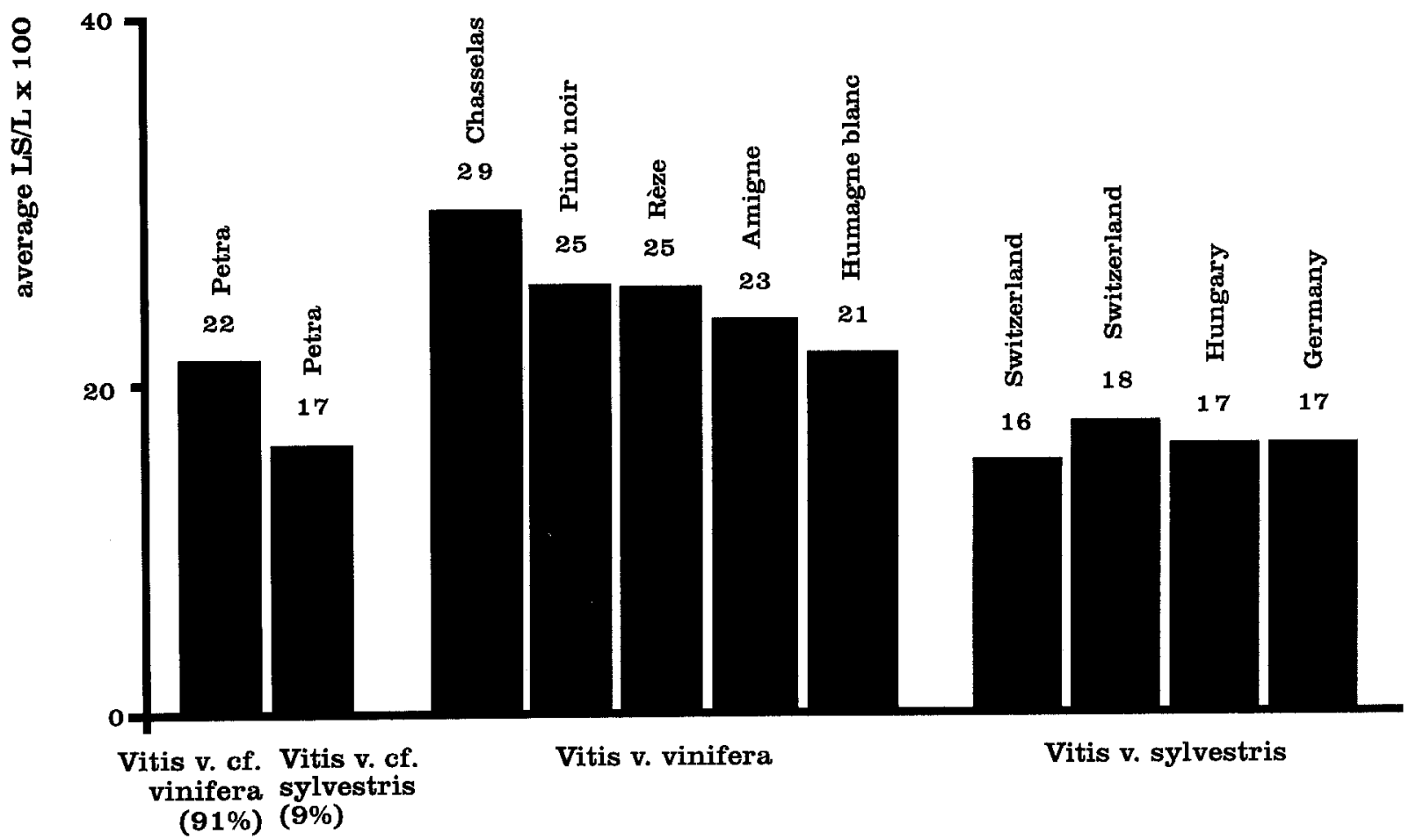

Fig. 5. Average values for the ratio of stalk length over pip length (after Perret 1997) 
measured). The same mean values of wild grape pips from three localities ranged between 16 - 18 (Switzerland, with measurements from 300 seeds from two individuals; Hungary, with 1018 seeds from 24 individuals; Germany, with 41 seeds from two individuals; Fig. 5). Based on this data, $91 \%$ of the pips from Petra belonged to cultivated grapevines (index $=22[19-30]$ ) and $9 \%$ to wild grapevines (index $=17[12-18]$ ). The cut-off point chosen here to separate wild from cultivated grapevines, however, is arbitrary, as the pips' dimensions from a same variety vary, and may overlap with those of wild grapevines. This is the case, for instance, of the White Humagne and Amigne varieties.

It is important to notice that the "sylvestris" type pip morphology can be associated not only with wild grapevines, but also with archaic varieties. Consequently, the seeds found at Petra could belong to a cultivated grapevine bearing fruits of wild type. This hypothesis seems to be validated by the existence of such varieties not only in Europe (Levadoux 1956; Rivera Nuñez and Walker 1989; Perret 1997), but also "... dans les régions même où ils [les premiers cépages cultivés] sont nés" (in the same regions where the first cultivated vines originated), namely in Transcaucasia (Levadoux 1956). In the Near East, these varieties are nowadays replaced by others, which are morphologically very different from the wild type. But the only diagnostic feature providing an effective distinction between wild and cultivated grapevines remains their reproductive biology, dioecious for the wild and hermaphrodite for the cultivated Vitis. The pips' morphological variability appears to be linked to the existence of numerous clones, rather than solely to characteristics appearing after cultivation (Rivera Nuñez and Walker 1989; Zohary 1995).

\section{Archaeological evidence}

The discovery of wine presses probably of Nabataean origin in the Beidha region, near Petra, indirectly confirms the existence of viticulture (Al-Muheisen 1990 $a, b)$.

Amphorae remains, originating from Rhodes and dated from the 3 rd century B.C., were discovered during the excavations (Schneider and Stucky 1993), as well as many Nabataean wine cups. They prove that wine was certainly imported and consumed, although it is hard to evaluate the importance of the two activities.

In addition to the ban on cereals, fruit tree cultivation and viticulture, the Nabataean laws also prohibited the construction of houses. But private houses were built at the beginning of the 1st century B.C. and therefore the Nabataean prohibitions were no more strictly respected by then, at the latest (Stucky 1996).

\section{Conclusion}

For the reasons outlined above, the grape pips found at Petra could be considered as representing cultivated grapevines, though the evidence is not conclusive. The methods used were elaborated on European observations and are yet to be confirmed with Near Eastern grape pips. The identification of Vitis remains problematic and uncertain.

Although grape remains occurred in many samples, more than $90 \%$ of the pips found at Petra originated from an oven or "taboun" (ez Zantur III). As they were accompanied by a few peduncle fragments, they probably represent pressing residues used as fuel. But the absence of charred grapevine wood among the archaeological remains examined came as a surprise, as other fruit trees, such as Olea europaea (olive tree) and Ficus carical pseudo-sycomorus (fig tree), were present. It is conceivable that, at least inside the town, grapevines were mainly used for ornamental purposes, helping to create cool and shady areas under the pergolas, as well as providing fruits.

Viticulture in the surrounding area is a possibility, however to take the example of the Nile valley, grapes and wine were largely imported into Egypt from Greece and Palestine during the 3rd millennium B.C., for climatic reasons (Zohary and Hopf 1997; McGovern et al. 1997). Was this also the case in Jordan? More archaeobotanical data is necessary to answer this question satisfactorily.

Acknowledgements. We thank Maria Mangafa for her help and the control of a sampling of pips, Georges Haldimann for photographing the grape pips, and Suzanne Eades for translating the French text.

\section{References}

Al-Mubeisen Z (1990a) Exemples d'installations hydrauliques et des techniques d'irrigation dans le domaine nabateen (PétraJordanie méridionale). In: Geyer B (dir) Techniques et pratiques hydro-agricoles traditionnelles en domaine irrigué. Actes du Colloque de Damas 1987, Librairie Orientaliste P. Geuthner, Paris, pp 507-513

Al-Muheisen Z (1990b) Maîtrise de l'eau et agriculture en Nabatène: l'exemple de Pétra. Aram 2: 205-220

Fall PL (1990) Deforestation in southern Jordan: Evidence from fossil Hyrax middens. In: Bottema S, Entjes-Nieborg G, Zeist W van (eds) Man's role in shaping of the eastern Mediterranean landscape, Proceedings of the INQA/BAI symposium of the impact of ancient man on the landscape of the eastern Mediterranean region and the Near East, Groningen, Netherlands, 6-9 March 1989. Balkema, Rotterdam, pp 271-282

Hopf M (1978) Plant remains, Strata V-I. In: Amiran R (ed), Early Arad. Israel Exploration Society, Jerusalem, pp 64-82

Hopf M (1983) Jericho plant remains. In: Kenyon KM, Holland TA (eds) Excavations at Jericho. British School of Archaeology in Jerusalem, London, pp 576-621

Karg S (1996) Pflanzenreste aus den nabatäischen und spätrömischen Schichten. In: Kolb B, Schmid S, Stucky R (eds) Petra ez Zantur I. Ergebnisse der Schweizerisch-Liechtensteinischen Ausgrabungen 1988-1992. Terra Archaeologica 2: $355-357$

Kislev ME (1988) Fruit Remains. In: Rothenberg B (ed) The Egyptian Mining Temple at Timna. Institute of Archaeology, University College London, London, pp 236-242

Kislev ME, Nadel N, Carmi I (1992) Epipalaeolithic (19 000 BP) cereal and fruit diet at Ohalo II, Sea of Galilee, Israel. Rev Palaeobot Palynol 73: 161-166 
Levadoux L (1956) Les populations sauvages et cultivées de Vitis vinifera $\mathrm{L}$. Annales de l'Amélioration des Plantes 1: 59-116

Logothetis B (1970) The development of the vine and of viticulture in Greece based on archaeological findings in the area (in Greek with English summary). Epistimoniki Epetiris tis Geoponikis kai Dasologikis Sholis, University of Thessaloniki 13: $167-249$

Logothetis B (1974) The contribution of the vine and the wine to the civilization of Greece and eastern Mediterranean (in Greek with French summary). Epistimoniki Epetiris tis Geoponikis kai Dasologikis Sholis, University of Thessaloniki 17: 5-286

Mangafa M, Kotsakis K (1996) A new method for the identification of wild and cultivated charred grape seeds. J Arch Sci 23: $409-418$

Martinoli D (1997) Etude archéobotanique de macrorestes végétaux d'époques nabatéenne et romaine tardive, ez Zantur, Pétra, Jordanie. Certificat de Botanique, Université de Neuchâtel et EPFZ

McGovem PE, Hartung U, Badler UR, Gluster DL, Exter LJ (1997) The beginnings of winemaking and viticulture in the ancient Near East and Egypt. Expedition 39(1): 3-21

Mouterde P (1970) Nouvelle flore du Liban et de la Syrie. 2/texte. Dar el-Machreq, Beirut

Perret M (1997) Caractérisation et évaluation du polymorphisme des génotypes sauvages et cultivés de Vitis vinifera $\mathrm{L}$. à l'aide de marqueurs RAPD et de certains traits morphologiques. Travail de diplôme, Université de Neuchâtel

Rivera Nuñez D, Walker MJ (1989) A review of palaeobotanical findings of early Vitis in the Mediterranean and the origins of cultivated grapevines, with special reference to new pointers to prehistoric exploitation in the western Mediterranean. Rev Palaeobot Palynol 61: 205 -237
Schneider C, Stucky RA (1993) Der Gewürz- und Weihrauchhandel in der Antike. In: Katalog zur Ausstellung in der Galerie "le point" Petra und die Weihrauchstrasse. Konzept Gut, Zurich, pp 14-17

Shehadeh N (1982) The climate of Jordan in the past and present. In: Hadidi A (ed) Studies in the history and archaeology of Jordan. Department of Antiquities, Amman, pp 25-37

Smith H, Jones G (1990) Experiments on the effects of charring on cultivated grapes. J Arch Sci 17: 317-327

Stucky RA (1996) Die Nabatäischen Bauten. In: Kolb B, Schmid S, Stucky R (eds) Petra ez Zantur I. Ergebnisse der Schweizerisch-Liechtensteinischen Ausgrabungen 1988-1992. Terra Archaeologica 2: 13-49

Stucky RA, Kolb B, Schmid SG, Gerber Y, Bellwald U, Jacquat C (1995) Swiss-Liechtenstein excavations at ez Zantur in Petra 1994, the sixth campaign. Annual of the Department of Antiquities of Jordan 39: 297-315

Stummer A (1911) Zur Urgeschichte der Rebe und des Weinbaues. Mitt anthropol Gesell Wien 41: 283-296

Terpò A (1976) The carpological examination of wild-growing vine species in Hungary. Acta Bot Acad Sci Hungaricae 22: $209-247$

Zohary D (1995) The domestication of the grapevine Vitis vinifera L. in the Near East. In: McGovern PE, Fleming SJ and Katz SH (eds) The origins and ancient history of wine. Gordon and Breach, Luxembourg, pp 23-30

Zohary D, Spiegel-Roy P (1975) Beginnings of Fruit Growing in the Old World. Science 187: 319-327

Zohary D, Hopf M (1993) Domestication of plants in the Old World. 2nd Edn, Clarendon Press, Oxford 